\title{
Phytoplasma diseases of coconut in India - root (wilt) and tatipaka diseases
}

\author{
J.J. Solomon ${ }^{1}$ and L. Geetha ${ }^{1}$
}

\begin{abstract}
Root (wilt) and Tatipaka diseases in India are caused by phytoplasma. Lethal yellowing disease in Caribbean region, Lethal yellowing like disease in west and east Africa and Coconut stem necrosis.in Sumatra and Peninsular Malaysia are phytoplasma induced diseases of coconut in other continents. Root wilt disease in India was first reported from Kerala in 1874.Tatipaka disease was first noticed in Andhra Pradesh after the 1949 cyclone. The progress made on various aspects including history, nature of spread, description of external \& internal symptoms, etiology abiotic factors, biotic agents implicated in transmission of disease, culturing, chemotherapy, screening of coconut germplasm, breeding for disease resistance/tolerance and disease management is detailed.
\end{abstract}

Key words: Root (wilt) disease, Tatipaka disease, phytoplasma, India

\section{Introduction}

Coconut palm (Cocos nucifera L.) is grown in over 93 countries in the humid tropics. It Is affected by a number of maladies-some of them are lethal and others of debilitating nature. In the past thirty years, the causes of several coconut diseases of previously uncertain etiology have been determined. Phytoplasma, virus, viroids and protozoan flagellates have been implicated as the cause of some of these diseases.

Phytoplasmas earlier referred as mycoplasma-like organisms (MLOs) are plant pathogenic mycoplasmas that are non-helical, nonculturable and transtmitted by arthropod insect vectors. Lethal yellowing disease in Caribbean region, Lethal yellowing like discase in west and east Africa and Coconut stem necrosis in Sumatra and Peninsular Malaysia are phytoplasma induced diseases of coconut in other continents. Root (wIlO and Tatipaka diseases in India are confirmed to be caused by phytoplasma.

\section{Root (wilt) disease}

\section{History of the disease}

Root (wilt) disease of coconut was first noticed mi the erstwhile princely State of Travancore around 1874 and became very much evident after the great floods of 1882. The disease was initially reported from three independent locations - Erattupetta area of Meenachil taluk, Kaviyoor and Kalloopara of Thiruvalla taluk and Kayangulam of Karthikappally taluk each at a distance of about 50 km (Butler, 1908; Pillai, 1911; Varghese, 1934). Since then the disease has spread from the original foci of infection and according to a survey made during 1984/85 it occurs in a contiguous manner in an area of 4,10,000 ha in eight out of the fourteen districts of the Kerala, State. It is also noticed in isolated pockets in the remaining six northern districts of the state and in the bordering districts of Tamil Nadu (Fig.1). The disease intensity in the contiguous disease tract ranged between

${ }^{1}$ Central Plantation Crops Research Institute, Regional Station, Kayangulam, India 


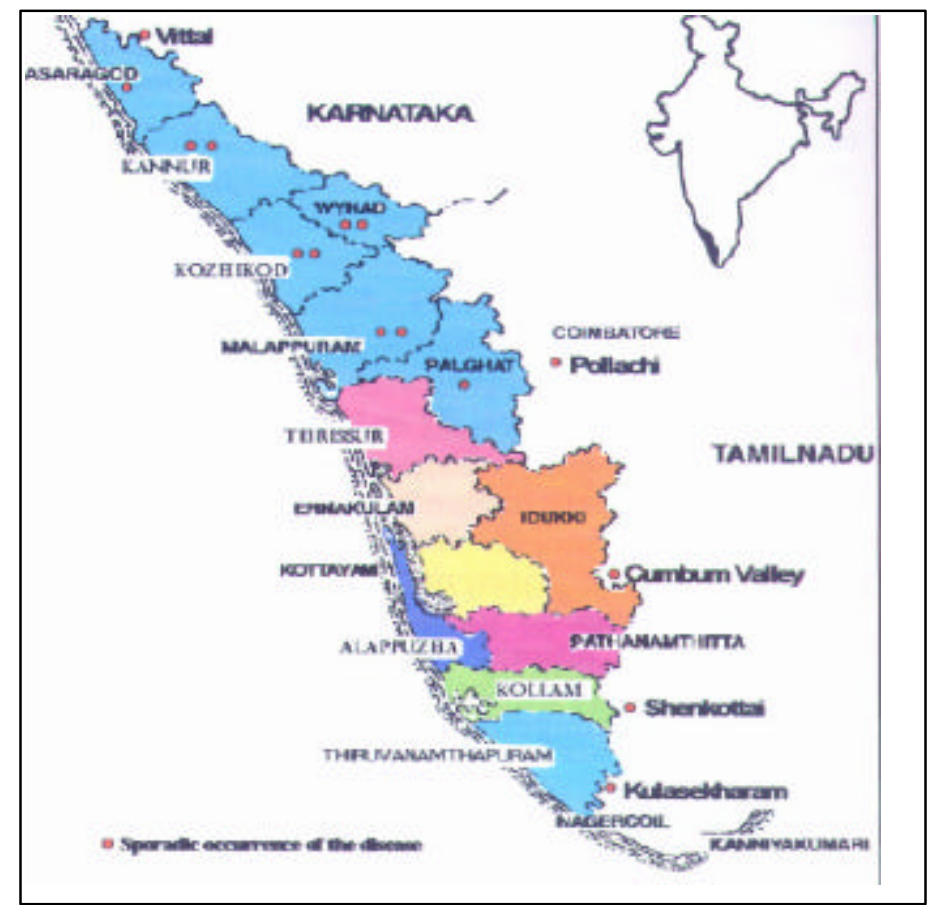

Fig. 1. Distribution of root (wilt) disease

$1.5 \%$ in Thiruvananthapurarn district to $75.6 \%$ in Kottayam district (CPCRI, 1985). Extent of disease incidence in eight southern districts was updated. in 1996 by a sample survey (Department of Agriculture, Government of Kerala, 1997) and it ranged from 2.1\% in Thiruvananthapurarn district to 48\% in Alapuzha district (Table 1). There is an overall reduction in disease incidence since 1984 from 32.37 to 24.05 . This is mainly attributed to the removal of about 59 lakh diseased palms, replanting with quality seedlings, adoption of disease management practices and crop conversion from coconut to rubber. The annual crop loss due to the disease was estimated to be about 968 million nuts (CPCRL 1985). The total estimated monetary loss in terms of loss in husk, copra yield and leaf number and quality of leaves on the basis of 1984 price index for coconut was of the order of about Rs.3000 million.

Table 1. Survey of coconut wilt in Kerala

\begin{tabular}{|c|c|c|}
\hline \multirow[t]{2}{*}{ Districts } & \multicolumn{2}{|c|}{ Disease inicidence $\%$} \\
\hline & $1984-85$ & $1996-97$ \\
\hline Thirissur & 2.60 & 6.19 \\
\hline Ernakulam & 34.51 & 33.01 \\
\hline Idukki & 34.18 & 33.56 \\
\hline Kottayam & 75.63 & 36.56 \\
\hline Alapphuza & 70.59 & 48.03 \\
\hline Pathanamthitta & 38.22 & 37.80 \\
\hline Kollmn & 28.55 & 25.97 \\
\hline Thiruvanandiapurarn & 1.52 & 2.09 \\
\hline Overall & 32.27 & 124.05 \\
\hline
\end{tabular}




\section{Nature and spread}

The disease is non-lethal but debilitating and palms of all age groups from seedlings to adult palms are affected. Disease contraction in the pre-bearing age, delayed flowering and affected the vitality of the palm. The leaf rot disease occurs superimposed on about $65 \%$ of the root (wilt) diseased palms (Srinivasan, 1991) and contributed to the rapid decline and reduction in yield of the affected palms. Colletothchum gloeosponoides arid Exserohilum rostralum are the main pathogens associated with the disease (Srinivasan and Gunasekharan, 1994).

The root (wilt) disease, occurs in all major soil types but the spread is faster in sandy, sandy loam, alluvial and in heavy textured soil than in latefite. Relatively higher incidence is recorded in waterlogged low lying areas adjacent to nvers and canals. The pattern of spread is erratic, occurs in jumps or leaps, characteristic of insect transnussion The rate of sprcad is reported to be about $1-4 \mathrm{~km}$ over a period of three years (Pillai, 1981).

\section{Symptoms}

\section{External symptoms}

The most obvious arid diagnostic symptom of the disease is die abnormal inward bending of the leaflets termed 'ribbing' or 'flaccidity'. Folliar yellowing of the outer whorl of leaves and marginal necrosis are the other associated symptoms (Radha and Lal. 1972) (Fig. 2).

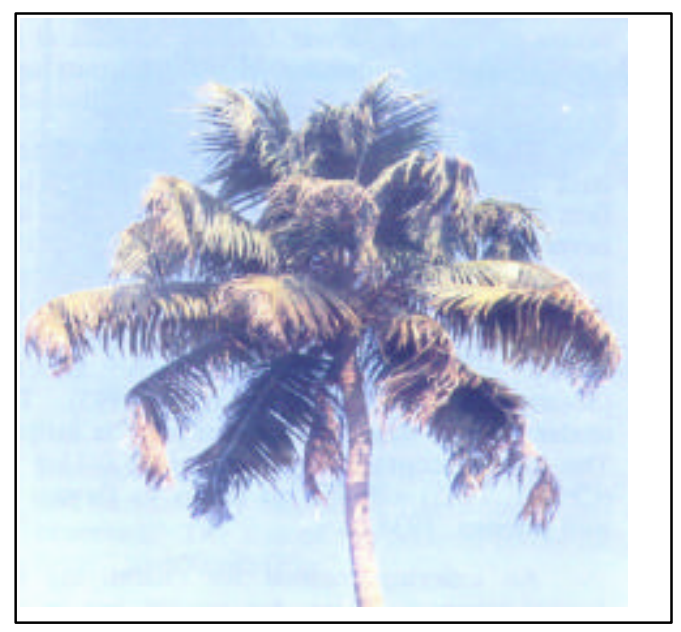

Fig. 2. Palm with root (wilt) symptom

In seedlings and juvenilc palms yellowing of foliage is virtually absent and 'flaccidity' is the only symptom evident. Instances of diseased palms having their outer leaves quite healthy but with yellowing of leaves in some of the inner whorls is also noticed (Menon, 1938). The root system in the early stage of disease is apparcntly nornial arid the percentages of rotten roots are few. However, with die progress of the disease, extensive rotting of roots is observed (Menon and Pandalai, 1958). The mam roots arid rootlets start drying from tip backwards (Menon and Nair, 1951). The capacity of the palms to regenerate fresh roots is drastically reduced (Michael, 1964).

Shedding of immature nuts if the tree is bearing at the time of disease contraction is yet another symptom observed in some cases (Menon, 1938). Drying up of spathes and necrosis of spikelets from tip downward in unopened inflorescence is noticed in certain cases. A higher percentage of pollen 
produced is eidier sterile or with low viability (Varkey and Davis, 1960). Meiotic irregularities are also observed (Nambiar and Prasannakumari, 1964).

The vitality of the diseased palms is so adversely affected that they produce small spathes with fewer female flowers. In the advanced stage the crown gets very much reduced in size and ceases to produce flower bunches. Radha et al. (1962) reported reduction in yield of nuts upto $80 \%$ in palms in the advanced stages of disease.

The nuts from diseased palms have thinner husk and fibers are definitely weaker and less firm. (Varghese, 1934). The kernel is thinner and never dries up into hard brittle copra but remains soft and flexible. Although no significant changes in the biochemical constituents of the coconut meal due to the disease were observed but the quality of coconut water was affected (Sosammma and Chandrasekaran, 1993). The tender coconut water of diseased palm is insipid. The loss of copra /oil per nut is 9.0/11.3 $\%$ (CPCRI, 1985) and the oil losses its flavour as well (Menon, 1938).

An indexing method for quantifying the disease intensity giving due weight age to the three predominant foliar symptoms has been developed (George and Radha, 1973; Nambiar and Pillai, 1985).

Internal symptoms

Comparative anatomical studies of the tender unopened leaves of healthy and root (wilt) affected palms revealed general stunting of epidermal cells, reduction in thickness of the cuticle on the adaxial side and differential rate of division of the upper epidermis in longitudinal and transverse plains in leaves of diseased palms. Reduction in wall thickness of cells, sclerenchymatous fibers and bundle sheath is also observed. These anatomical changes may be contributing to the downward curling of leaflets (Joseph and Shanta, 1964).

The distribution of stomata per unit area is found to be more in leaflets of diseased palms (Joseph and Shanta, 1964). The stomatal regulation is adversely affected due to the disease irrespective of the age of the palm, time of the day and season. The stomata in diseased palms failed to close in response to soil and atmospheric drought. The excessive transpirational loss in diseased palm due to impaired stomatal mechanism is not replenished adequately as the root system is damaged (Rajagopal et al., $1986 \mathrm{a}, \mathrm{b}$ ). The overall disturbance in water relation caused to the two facets of water transport namely absorption and transpiration may also be contributing to the flaccidity symptoms.

Gross structural changes are also very much evident in vascular tissues of diseased palms. Wall thickness of metaxylem elements is reduced resulting in uneven shape of the xylem component. The uptake and translocation of solutes is also impeded with the formation of tyloses in xylem vessels, gummosis and necrotic obliteration of phloem in the roots of diseased palms (Govindankutty, 1981). Leaching of metabolites due to permeability changes also aggravates the disease syndrome (CPCRI, 1977).

\section{Etiology}

A number of biotic agents and abiotic factors were implicated as the cause of the disease.

\section{Abiotic factors}

Physiological and biochemical changes observed in diseased palms such as derangement in uptake and translocation of solutes, higher respiration and transpiration rate, altered nitrogen 
metabolism and an accelerated phenol metabolism are indicative of a pathogen mediated aberrant host metabolism than of a physiological disorder (Mathew et al., 1991).

Soil sickness as a contributing factor of the disease was also excluded based on field fertility trials and analysis of tissue and soil (Cecil and Amma, 1991).

\section{Biotic agents}

The sporadic occurrence and spreading nature of the disease implied the involvement of a pathogen as the cause of the disease. A number of biological agents such as fungi, bacteria and nematodes were reported to be associated with the disease. However, pathogenicity experiments with these organisms singly and in combination failed to reproduce the symptoms of the disease thereby, indicating their non-involvement in the disease causation (Joseph and Lilly, 1991, Jayasankar and George, 1991; Sosamma and Koshy, 1991). Nagaraj et al. (1954) based on the systemic nature of the disease and resemblance of symptoms to other known plant virus induced diseases (yellows type) suggested it to be a virus disease. Association of a virus with the disease was also indicated through transmission studies (Nagaraj and Menon, 1956; Shanta et al., 1964). Summanwar et al. (1969) reported the isolation of a virus frorn Chenopodium amaranticolorThe virus was also identified as a strain of TMV based on its reaction to TMV antiscrum (Summanwar et al., 1971). However, subsequent systernatic serological and electron microscopic studies have conclusively ruled out the association of any virus with the disease (Shanta et al., 1975). Similarly, Maramorosch and Kondo (1977) reported the presence of icosahedral particles in epidermis and ground parenchyma cells of root (wilt) diseased palms. These particles were later identified as plasmodesmata sectioned in tangential plane (Parthasarathy, 1978). Polyacrylamide gel electrophoretic analysis of isolated nucleic acids frorn diseased palms also failed to subscribe to a viroid etiology (Randles and Hatta, 1980).

\section{Phytoplasma}

Structural alterations observed such as disorganisation and disintegration of vascular tissues, increased chromophily and necrotic obliteration of phloem tissues suggested the involvement of a vascular bound pathogen.

\section{Electron microscopy}

Electron microscopic examination of juvenile tissues like sub-meristem, petiole of developing leaves, rachilla of unopened inflorescence and root tips of diseased palms revealed the presence of phytoplasma (Solomon et al., 1983). Phytoplasmas earlier referred as mycoplasma-like organisms (MLOs) are plant pathogenic mycoplasmas that are non-helical, non culturable and transmitted by arthropod insect vectors (Tully, 1993). The prokaryotes are phloem bound and observed only in sieve tubes. The mollicutes are delimited by a trilamellar unit membrane and contained DNA strands and ribosomes (Solomon, 1991). Pleomorphic forms varying from circular to oval and occasionally beaded or filamentous ones are observed. The size of the coccoid forms ranged frorn 250-400 nm (Fig.3).

In sieve tubes the phytoplasma generally occupied a parietal position close to the sieve tube wall or seen in proximity to sieve plates (Solomon, 1997). Distribution of the phytoplasma within the vascular bundle is rather sparse and not all sieve elements in a patch contained them. Some of the bundles are totally free of the organism. In the older leaves moribund forms lacking internal contents only were observed (Solomon and Geetha, 1993). The apparent absence of phytoplasma in mature parts and their occurrence in tender tissues suggest the movement of the organism in the phloem assimilate to the "sink region". 


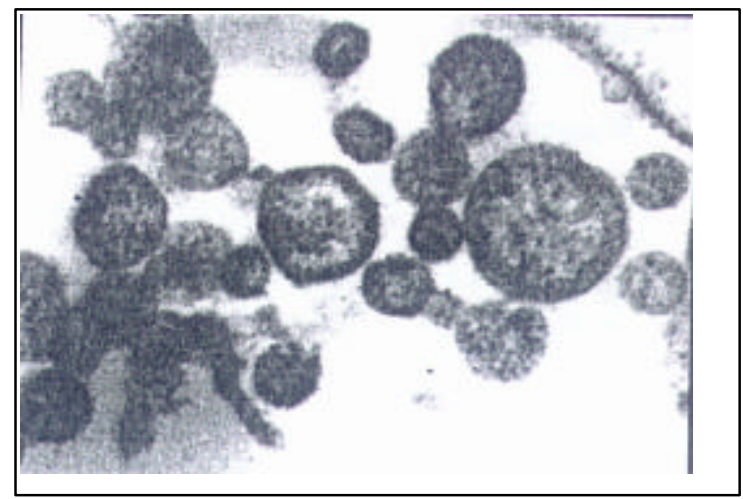

Fig. 3. Phytoplasma in sieve tube of tender rachilla of root (wilt) disease

Constant association of phytoplasma with the disease has been conclusively established with the finding of the organism in more than eighty diseased palms and their absence in seventy-five healthy palms studied. The palms examined are of various age groups, intensities of disease and from different locations. None of the other biological agents reported earlier to be associated with the disease could be observed in the vascular tissues (Solomon et al., 1999). The possible association of trypanosomatid flagellates was also studied by examining rachilla of inflorescence of six palms each in the early, middle and advanced stages of disease. The protozoan flagellate was not observed in any of the samples (CPCRI, 1991).

\section{Transmission}

Insects belonging to the Homoptera group generally transmit Phytoplasmas with the exception of a member of the Pentatomorpha of the heteropterous group. Record of insects on coconut in India did not enlist any belonging to this group. Hence an inventory of insects on coconut was made using various traps and through direct examination of coconut foliage. This led to the identification of a leaf hopper Suphonia greeni, a plant hopper, Proutista moesta, both belonging to the Homopteran group, besides lace wing bug, Stephanitis typica (Tingidae) already known putative vector (Rajan and Mathen, 1984; 1985). A rapid survey of representative gardens in the eight southern dstricts where the disease is prevalent in a antiguous manner confirmed the presence of all the three insects.

Acquisition of phytoplasma by these patative insect vectors while feeding on diseased palm was studied. Phytoplasma was observed in the salivary glands of lace bug 18-23 days after feeding on diseased palms (Mathen et al., 1987) and also in plant hoppers fed on diseased palms for over 30 days (CPCRI, 1991; Rajan et al., 2002). The vector role of lace wing bug and plant dipper have been conclusively established in transmission experiments (Mathen et al., 1990; CPCRI, 1996).

Field experiments were conducted to assess the control of aerial insects on fresh incidence of disease. Even fortnightly spraying of insecticide with higher concentration of both systemic and contact insecticide could not protect the seedlings from disease contraction. The perennial nature of the crop, the presence of insect vector throughout the year, the persistent mode of transmission of phypoplasma and the reinfestation of sprayed plants within a short period may be the attributing factors for the failure to control the disease. Large scale chemical treatments, at frequent intervals also would be costly and can use environmental hazards (Solomon et al., 1999).

The phytoplasma also could be experimentally transmitted frorn coconut to periwinkle, a mycoplasmal indicator host through dodder laurel (Cassytha filiformis). Periwinkle grown in insect proof cages bridged to diseased coconut palms through dodder laurel developed chlorotic spots in the 
interveinal areas and at vein endings of fully opened leaves in three to four weeks of haustorial establishment. Detection of phytoplasma in periwinkle, dodder laurel and the source palm confirmed transmission of the disease (Sasikala et al., 1988).

\section{Culturing}

Although the phytoplasma associated with root (wilt) disease had been transmitted through insect vector to coconut seedlings and to periwinkle through the dodder laurel, culturing of the organism in cell- free medium and -assessing its pathogenicity is one of the basic tenet of Koch's postulate. Phytoplasmas as a group have not been cultured so far in cell- free medium. Nevertheless concerted effort was made to culture the organism from rachilla of unopened inflorescence, spear leaf, mid vein and vascular sap frorn root (wilt) diseased palms, petiole and mid vein of symptomatic periwinkle and infective lace bugs in about 40 different media (CPCRI, 1988, 1989a; Solomon et al., 1999).

Phloem sap, as such or supplemented with serum is found to be an ideal medium for culturing fastidious organisms such as Acholeplasma laidlawii, Mycoplasmafermentans, Spiroplasma citri and Phytomonas davidii (EdenGreen and Waters, 1982; Mc Coy, 1976, 1977, 1978). A method for aseptic collection of vascular sap, in unmodified form, from inflorescence of coconut palms in ice packed vacuum flasks was standardised and the biochemical constituents of the sap from apparently healthy and diseased palms analysed (Rajagopal et al., 1988; Chempakarn and Rajagopal, 1989). The data provided a rationale for formulation of new media. Freshly collected vascular sap from apparently healthy palms as such or supplemented with nutrients was tried as potential medium for culturing. Coconut water from nuts of healthy palms was also used as a basal constituent of certain media. However the intraphloemic phytoplasma was found not amenable to culturing in any of the medium (CPCRI, 1989b).

Attempts were made to culture the root (wilt) phytoplasma in chick embryos by employing different routes of inoculation and varying cultural conditions. Although in an identical study the mycoplasma associated with phyllody disease in sesamum could be cultured in chick embryos, the root (wilt) organism had defied culturing in this potential medium also, confirming its non-adaptability to environment outside the phloem tissue (Srinivasan and Solomon, 1992).

Similarly, attempt was also made to maintain the organism in insect tissues through organ culture. Excised salivary glands arid midgut segments of infective lacewing bug and plant hopper were inoculated to insect tissue culture medium. Phytoplasma could not be maintained in the insect tissues in culture.

Another line of investigation pursued at present is on maintenance of phytoplasmas in plant tissues micropropagated in vitro in tissue culture media. Phytoplasma with internal contents could be observed in the roots in culture up to nine months and thereafter only moribund forms were evident (Solomon et al., 1999).

\section{Chemotherapy}

Phytoplasmas being non-cultivable in cellfree media posed a problem in testing its pathogenicity and fulfilling the Koch's postulates mandate. Characteristically the prokaryotes lacking a cell wall and delimited by cell membrane ate insensitive to penicillin and are sensitive to tetracycline group of antibiotics. This differential chemotherapeutic response is accepted and used as an adjunct to provide circumstantial evidence on the etiology of phytoplasma. induced diseases. To assess the efficacy of any antibiotic on the organism it should be ensured that the chemical reaches the target site in unaltered state within a reasonable period. Pillai and Raju (1985) had fabricated a pneumatic pressure injector 
for administering the antibiotic. The uptake and translocation of the antibiotic administered was studied employing a tracking dye and through bioassay using Bacillus cereus sub sp. mycoides as the test organism. The antibiotic could be detected in the foliage within $24 \mathrm{hr}$ of its application and traces of the chernical persisted up to 12 weeks (Chowdappa et al., 1989). Since tetracyclines are not mycoplasmacidal but ate mycoplasmastatic only the antibiotic needs to be administered to the plant when the concentration petered out. Based on the results of the bioassay studies, quarterly application of the antibiotics was stipulated. Results of the field trial undertaken in two locations with four concentrations of Oxytetracycline hydrochloride (OTC-Terramycin Tree Formulation of M/s Pfizer India Ltd.) a single concentration each of Neomycin, Penicillin and distilled water control revealed remission of symptoms in $53 \%$ of the palms treated with 3 and $6 \mathrm{~g}$ a.i. of OTC. Palms treated with Penicillin arid distilled water control deteriorated over the pretreatment condition thus providing further evidence to the mycoplasmal etiology of the disease (Pillai et al., 1991). The field application of OTC however cannot be recommended either as a prophylactic or curative measure as the antibiotic needs to be given repetitively and temporary remission of symptom only is obtained. Prohibitive cost of the antibiotic and the caution against its indiscriminate use for treating any plant disease are the other factors, which should weigh against it being recommended as a treatment.

\section{Screening of coconut germplasm}

Field evaluation of 63 cultivars and 32 hybrid combinations since 1972 indicated that none of the cultivars/hybrids manifest resistance/tolerance to the disease (Jacob et al., 1991). However the hybrid, Chow ghat Orange Dwarf (COD) x West Coast Tall (WCT) under ideal management yielded higher number of nuts compared to WCT palms of identical age in the early years of production (Cecil and Amma. 1998). Germplasm collection (24 exotic accessions) made from South Pacific Ocean Islands in 1981 have been planted at the World Coconut Germplasm Center at Sipighat in Andamans with a view to screening their progenies arid different cross combinations against the disease (Jacob et al., 1998).

\section{Breeding for disease resistance/tolerance}

An intensive survey was conducted in the heavily diseased hot spot areas to locate high yielding apparently healthy WCT palms of over 35 years. About 200 palms have been so far identified in hot spots of Alappuzha, Pathanamthitta, Kollam and Kottayam Districts of Kerala State. Chowghat Green Dwarf (CGD) showed field tolerance of over 90 per cent to root (wilt) disease (CPCRI, 1972). About 110 CGD and 75 WCT disease free palms identified in hot spots are being used in the crossing programme in various combinations. About 6000 seedling progenies raised from the crosses involving disease free WCT and CGD mother palms in hot spots have so far been planted in five locations to establish nucleus seed gardens at Thrissur, Kottayam, Alappuzha and Kollam Districts. These plants when come to bearing will partly meet the planting requirements of these districts (CPCRI, 2003).

\section{Disease management}

One of the significant features of the disease is that it is not lethal but a debilitating malady, which responds to ideal management. Two strategies, one for the heavily diseased contiguous area, and another for the mildly affected area have been formulated. In the heavily diseased are, the yield of palms can be sustained or even improved through adoption of integrated management practicesremoval of disease advanced and juvenile palms, balanced fertiliser application, addition of organic manures, raising of green mature crops in the basins and incorporation, irrigation during summer months, practicing plant protection methods and adoptiong inter and mixed cropping (CPCRI, 1986). Mixed farming in the diseased gardens involving the raising of fodder crops in the inter spaces, maintaining milch cows and recycling of organic waste has aided in increasing the yield of palms by 28.1 (Sahasranaman et al., 1983). Mixed cropping with cocoa increased the yeild by $27-3 \%$ and 
slowed down th edecline of palms (Amma et al., 1982). Similarly, cultivation of tuber crops such as tapioca, elephant foot yam and yams in the interspaces of palms in the disease affected gardens for a period of three years increased the nut yield by 4.96 to 15.57 and $8.07 \%$ respectively (Menon and Nair, 1978).

The strategy for the mildly affected area in to contain the disease by removing all the diseased palms. Following the eradication of a few diseased palms at Shenkotta (Tamil Nadu) and at Nadathara (Kerala) in 1971, recurrence was not noticed susequently (CPCRI, 1986). With the above encouraging results an attempt was made to arrest the spread of the disease beyond Karuvannoor River in Thrissur district and to contain it within the geographical limits. With the removal of 730 disease could be brought to just 21 palms spread over in 15 gardens in three villages in 1989-1990 (Muralidharan et al., 1998).

Since there are no currative or prophylactic measures available to combat the disease the longterm option is to breed for disease resistance. Concurrently adoption of recommended management practices could yield economic returns per unit area. Systematic rouging of diseased palms in the mildly affected area could prevent the further spread of the disease.

\section{Tatipaka disease}

\section{Occurrence, distribution and crop loss}

Tatipaka disease was first noticed in Andhra Pradesh after the 1949 cyclone and named as 'Tatipaka' disease after the village in which it was first noticed. (Rao et al., 1956). The disease is endemic to East and West Godavari, Srikakulam, Nellore, Krishna and Guntur districts (Subbiah and Rao, 1963; Rethinam et al. 1989). It generally occurs in heavy black deltaic soils than in sandy, sandy loan and red loam soils. The disease is observed in well-managed and neglected gardens. A survey made during 1985-1990 in the central delta of the river Godavari "Konaseema" which account for $60 \%$ of the area under coconut in the state indicated that the disease is prevalent in 85 out of 201 villages (Narasimhachari et al., 1991). About 8179 palms were identified as Tatipaka diseased (Rajamannar et al., 1993).

The disease is non-lethal but of a debilitating nature, generally affecting palms in the age groups of 20-60 years. Palms below 20 years are very rarely affected (Rethinam et al, 1989). The spread of the disease is not contiguous but sporadic at a slow pace of $3.5 \%$ over a period of five years.

\section{Symptoms}

The disease-affected palms generally bear profusely for 2-3 years before the expression of foliar symptoms and more number of dark leaves; often fasciated appears in the crown. With the onset of disease there is a reduction in both number and. size of leaves (Fig. 4). The leaves exhibit characteristic chlorotic water soaked spots and the fronds bend abnormally sometimes twisting in loops. In the advanced stage with the narrowing of leaflets arid reduction in size of crown, the affected. palm looks like a Date pahn in appearance (Fig. 5). The spathes produced arc very small with very few rachilla. The bunches contain a mixture of normal and atrophied nuts (Fig. 6). The atrophied nuts are barren with thinner spongy mesocarp with or without shell, copra arid nut water. The undersized nuts show longitudinal cracks with occasional gumming. In the advanced stage of the disease the stem tapers and produces smaller spathes arid inflorescences, which ultimately do not bear any fruit (Rao, 1966; Ramapandu and Rajamannar, 1981). 


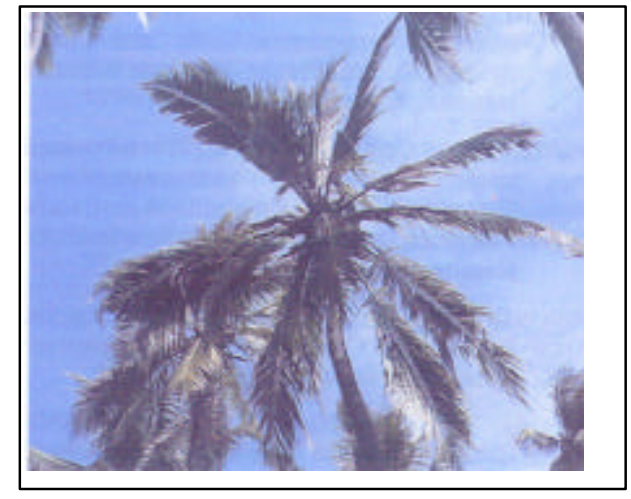

Fig. 4. Symptoms of Tatipaka disease

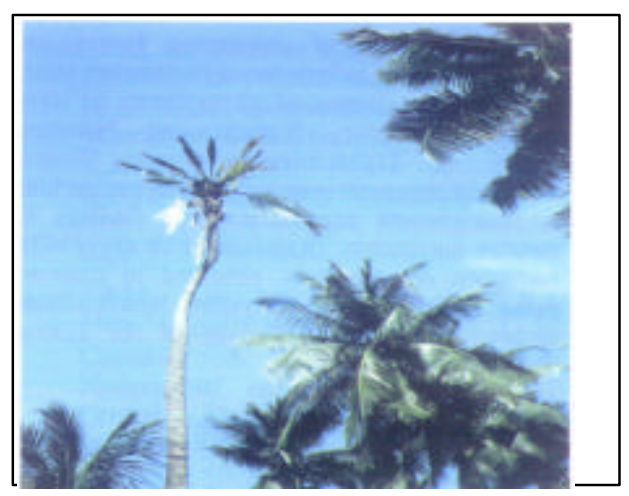

Fig. 5. Tatipaka diseased palm

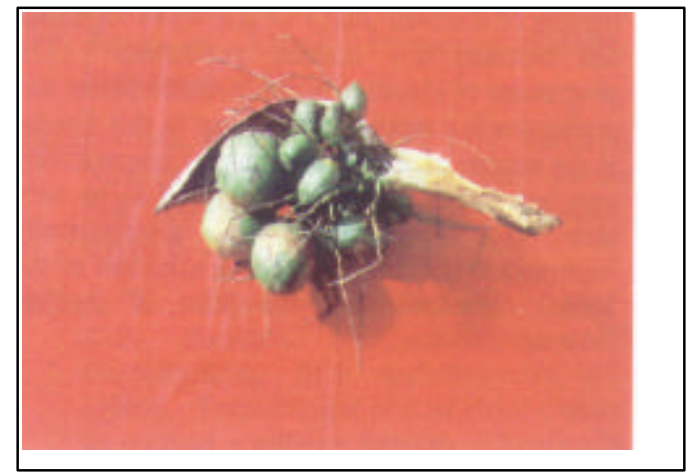

Fig. 6. Normal and atrophied nuts in a bunch

\section{Etiology}

The disease was considered. as one of unceftain etiology till recently. The involvement of fungi and bacteria, in the incidence of the disease was conclusively ruled out, as these microbes could not be consistently isolated from diseased palms. Sap transmission and purification studies have also ruled out virus as the etiological agent of the disease (Ramapandu arid Rajamannar, 1981; Rajamannar et $a l, 1984)$. Polyacrylamide gel electrophoretic analysis of isolated nucleic acid from Tatipaka discased palms did not identify any viroid type pathogen either (Randles and Hatta, 1980). Electron microscopic examination of tender roots, sub-meristem, petiole of developing leaves and rachilla of tender inflorescence of diseased palms revealed the presence of phytoplasma in sieve tubes (Rajamannar, Prasadji and Solomonunpublished). Light microscopy using Dienes' stain and fluorescent microscopy with aniline blue as fluorochrome corroborated the findings of electron microscopy (Rajamarmar et al., 1993). Remission of symptoms observed in diseased palms treated with tetracycline hydrochloride further confirmed the etiology of the disease (Rajamannar et al., 1993).

\section{Screening for disease resistance}

Survey of the heavily diseased area indicated the cultivar; Gangabondam to be free of disease and the incidence was high on the East Coast Tall. This observation has to be confirmed so that this cultivar could be used as a parent in the ftiture breeding programme for evolving disease resistant genotypes. 


\section{Disease management}

Attempts to control the disease by foliar and soil application of various chemicals, hormones and nutrients did not yield any encouraging results. Root regeneration of affected palms also could not ameliorate the condition of palms (Rajamannar et al. 1993).

Since there are no prophylactic or curative measures available for treating phytoplasmal diseased plants, the option left are to arrest the spread of disease by systematic surveillance and roguing of diseased palms as and when identified and breeding for disease resistance. The programme of identifying the diseased palms and eradication is a more practical step in this disease as the number of diseased palms is comparatively very low and the spread is reported to be very slow. The programme if systematically implemented will help in total eradication of the Tatipaka disease from the State of Andhra Pradesh.

\section{References}

Amma, P.G.K., Menon, K.S., Patil. P.B. and Sadanandan 1982. Effect of mixed cropping with Cacao in coconut root (wilt) affected garden. Indian Cocon. J. 13 (4): 14-17.

Butler, E.J. 1908. Report on coconut palm disease in Travancore. Agric. Res. Inst. Pusa. Bull. No. $9,23 \mathrm{pp}$.

Cecil, S.R. and Amma, P.G.K. 1991. Soils and nutrition, pp. 45-52.1n: Coconut Root (Wilt) Disease, Monograph Series No. 3. M.K. Nair, K.K.N. Nambiar, P. K. Koshy and, N.P. Jayasankar (Eds.). Central Plantation Crops Research Institute, Kasaragod, India, 92pp.

Cecil, S.R. and Amma, P.G.K. 1998. Soils and nutrition, pp.53-63. In: Coconut Root (Wilt) Disease, K.U.K. Nampoothiri and P.K. Koshy, (Eds.) Central. Plantation Crops Research Institute, Kasaragod, India.

CPCRI, 1972. Annual Report for 1971. Central Plantation Crops Research Institute. Kasaragod, India, 212pp.

CPCRI, 1977. Annual Report for 1976. Central Plantation Crops Research Institute, Kasaragod, India, 283pp.

CPCRI, 1985.Coconut root (wilt) disease. Intensity, production loss and future strategy Central Plantation Crops Research Institute, Kasaragod, India, 45pp.

CPCRI, 1986. Coconut root (wilt) disease-present status of research and management. Technical Bulletin No. 14. Central Plantation Crops Research Institute, Kasaragod, 10 pp.

CPCRI, 1988. Annual Report for 1987. Central Plantation Crops Research Institute, Kasaragod, India, 174pp.

CPCRI, 1989a. Annual Report for 1988. Central Plantation Crops Research Institute, Kasaragod, India, 186pp.

CPCRI, 1989b. Coconut Root (Wilt) Disease - A Discourse. Tech. Bull. 19. Central Plantation Crops Research Institute Kasaragod, India, 12pp. 
CPCRI, 1991. Annual Report for 1990-1991. Central Plantation Crops Research Institute, Kasaragod, India, 154pp.

CPCRI, 1996. Research Highlights 1995-1996. Central Plantation. Crops Research Institute Kasaragod, India, 25pp.

CPCRI, 2003. Annual Report for 2002. Central Plantation Crops Research Institute Kasaragod, India, 178pp.

Chempakam, B. and Rajagopal, V. 1989. Biochemical composition of vascular sap from the inflorescence of apparently healthy and root (wilt) diseased coconut palms. J. Plawn. Crops 16 (Suppl.): 41-46.

Chowdappa, P., Gopinathan Pillai, N., Gunasekaran, M. and Solomon, J.J. 1989. Distribution and retention of Oxytetracycline hydrochloride injected into coconut palms affected by root (wilt) disease. J. Plawn. Crops 17(2): 108-113.

Deeley, J., Stevans, W.A. and Fox, R.T.V. 1979. Use of Dienes' stain to detect plant diseases induced by mycoplasma like organisms. Phytopathology 69: 1169-1171.

Department of Agriculture, Government of Kerala (1997). Coconut root (wilt) survey, 1996,55pp.

Eden Green, S. J. and Waters, H. 1982. Collection and properties of phloem sap from healthy and lethal yellowing diseased coconut palms in Jamaica. Phytopathology 72: 667-672.

George, M. V. and Radha, K. 1973. Computation of disease index of root (wilt) disease of coconut. Indian J. Agric. Sci. 43: 366-370.

Govindankutty, M.P. 1981. Histopathological studies, pp.49-54. In: Review of Research on Coconut Root (wilt) Disease. Central Plantation Crops Research institute, Regional Station, Kayamkulam

Jacob, P.M and Rawther T.S.S. 1991. Varietal resistance in coconut root (wilt) disease, pp.67-80. In: Coconut Root (Wilt) Disease, Monograph Series No. 3. M.K. Nair, K.K.N. Nambiar, P. K. Koshy and N.P. Jayasankar (Eds.). Central Plantation Crops Research Institute, Kasaragod,lndia, 92pp.

Jacob, P.M., Nair. R.V., and Rawther T.S.S. 1998. Varietal resistance pp 97-104. In: Coconut root (wilt) disease, K.U.K. Nampoothiri and P.K. Koshy (Eds.). Central Plantation Crops Research Institute, Kasaragod,India.

Jayasankar, N.P. and George, M. 1991. Etiology -B. Bacteria pp. 17-18. In: Coconut Root (Wilt) Disease, Monograph Series No. 3. M.K. Nair, K.K.N. Nambiar, P. K. Koshy and N.P. Jayasankar (Eds.). Central Plantation Crops Research Institute, Kasaragod, lndia, 92pp.

Joseph, T. and Shanta, P. 1964. Anatomical changes in the tissues of the tender leaves of coconut palms affected by the root (wilt) disease. J. Indian Bot. Soc. 42: 6165.

Joseph, T. and Lilly, V.G. 1991. Etiology - A. Fungi, In: Coconut Root (Wilt) Disease, Monograph Series No. 3. M.K. Nair, K.K.N. Nambiar, P. K. Koshy and N.P. Jayasankar(Eds.). Central Plantation Crops Research Institute, Kasaragod, India, 92pp. In: Coconut Root (Wilt) disease. 
Monograph Series No.3. pp 13-15. Central Plantation. Crops Research Institute, Kasaragod, India.

Maramorosch, K. and Kondo, F. 1977. Electron Microscopy of leaf sections from Kerala wilt diseased coconut palm. J. Plawn. Crops 5: 20-22.

Mathen, K., Rajan, P., Radhakrishnan Nair, C.P., Sasikala, M.,Gunasekaran, M., Govindankutty, M.P. and Solomon, J.J. (1990). Transmission of root (wilt) disease to coconut seedlings through Stephanitis typica (Distant) (Heteroptera; Tingidae). Trop1. Agri. (Trinidad) 67(1): 69-73.

Mathen, K., Solomon, J.J., Rajan, P. and Geetha, L. 1987. Electron microscopic evidence on the role of Stephanitis typica (Distant) as vector of Coconut root (wilt) disease. Curr. Sci. 56: 1339-1341

Mathew, C., Rajagopal, V., Varkey, T. and Joseph, K.V. 1991. Physiology and biochemistry, pp 53-59 In. Coconut Root (wilt) Disease. Monograph. Series No.3. Central Plantation Crops Research Institute, Kasaragod, India.

McCoy, R.E. 1976. Plant phloem sap: a potential mycoplasma growth medium. Proc. Soc.Gen.Microbiol.3: 155.

McCoy, R.E. 1977. Growth of mycoplasmas in phloem sap from lethal yellowing resistant Malayan dwarf coconut palm. Proc. Am. Phytopathol. Soc. 4:108.

McCoy, R.E. 1978. Growth of plant parasitic protozoan Phytomonas davidi in mycoplasma media and in plant phloem sap. Phytopath. News 12: 217.

Menon, K.P.V. and Pandalai, K.M. 1958. The Coconut Palm - A Monograph. Indian Central Coconut Committee, Ernakulam. 384 pp.

Menon, K.P.V. 1938. Report on the scheme of Investigations on the diseases of coconuts in South India, 16pp.

Menon, K.P.V. and Nair, U.K. 1951. Scheme for the investigation of the root and leaf diseases of the coconut palm in South India. Consolidated final report of the work done from 8th March 1937 to 31st March, 1948. Indian Cocon. J. 5 (1): 319.

Menon, K.S. and Nayar, T.V.R. 1978. Effect of intercropping with tuber crops in root (wilt) affected coconut gardens, Proc. PLACROSYM 1: 416-424.

Michael, K.J. 1964. Studies on the root system of the coconut palm. Indian Cocon.J.17: 91-98.

Muralidharan, A., Jayasankar, N.P., Antony, K.J. and Rethinam, P. 1998. Management, pp. 105-114. In: Coconut Root (wilt) Disease. CPCRI, Kasaragod, India.

Nagaraj, A.N. and Menon, K.P.V. 1956. Note on the etiology of the wilt (root) disease of coconut palm in Travancore-cochin. Indian Cocon. J. 9: 161-165.

Nagaraj, A.N., Davis, T.A. and Menon, K.P.V. 1954. Sap transfusion a new device for virus transmission trials in palms. Indian Cocon. J., 7: 91-98.

Nambiar, M.C. and Prasannakumari, T.O. 1964. Effect of root (wilt) disease in the microsporogenesis in coconut. J. Plant. Crops 17: 93-100. 
Nambiar, P.T.N. and Pillai, N.G. 1985. A simplified method for indexing root (wilt) affected coconut palm. J. Plant. Crops, 13 (1): 35-37.

Narasimhachari, C.L., Prasadji, J.K. and Rajamannar M. 1991. Survey and confirmation of Tatipaka diseased palms in central delta of river Godavari in Andhra Pradesh. Indian Cocon. J. 22 (3): 7-10.

Oropeza, C, Santamaria, J. and Ashburner, G.R. 1997. A model for the pathogenicity of lethal yellowing in coconut palms (Cocos nucifera L.). In: International Workshop on Lethal Yellowing-Like Diseases of Coconut, S.J Eden-Green and F. Ofori (Eds.). Elminal Ghana, 5-10 Nov. 1995. Natural Resources Institute, Chatham, U. K.

Parthasarathy, M.V. 1978. Have virus like particles been found in leaf of Kerala wilt diseased coconut palms? Not yet. J. Plantn. Crops 6: 87-89.

Pillali,N.G., Chowdappa, P., Solomon, JJ and Mathen, K. 1991. Remission of symptoms of root (wilt) disease of coconut injected with Oxytetracycline-HCI. J. Plant. Crops 19:14-20.

Pillai, N.G.1981.In: Review of Research on Coconut Root (wilt) Disease. Central Plantation Crops Research Institute, Regional station, Kayamkulam, p.90 (Mimeo).

Pillai, N.G. and Raju, C.A. 1985. A simple pressure injection device for application of antibiotics on coconut palm. J. Plant. Crops 13: 151-154.

Pillai, N. K. 1911. Naleekeram. Vidyabhivardhini Press, Quilon, 112 pp.

Radha, K. and Lal, S.B. 1972. Diagnostic symptoms of root (wilt) disease of coconut. Indian J. Agric. Sci. 42: 410-413.

Radha, K., Sahasranaman, K.M. and Menon, K.P.V. 1962. A note on the yield of coconut in relation to rainfall and leaf rot and root (wilt) disease. Indian Cocon. J. 16: 3-11.

Rajagopal, V., Chempakam, B., Amma, P.G.K. and Cecil, S.R. 1988. Method of collection and properties of vascular sap from the inflorescences of healthy and root (wilt) diseased coconut palm. Plant Physiol. Biochem. 15: 308-312.

Rajagopal, V., Patil, K.D., Mathew. C. apd Amma, B.S.K. 1986a. Abnormal stomatal opening in coconut palms affected with root(wilt) disease. J. Exp. Bot. 37: 13981405.

Rajagopal, V., Patil, K.D., Mathew.C. and Amma, B.S.K. 1986b. Water relation studies in the root (wilt) affected coconut palms. In: Final Report Central Plantation Crops Research Institute, Regional station, Kayamkulam, Kerala, India, 24pp.

Rajamannar, M., Prasadji, J.K and Rethinam, P. 1993.Tatipaka disease of Coconut-Current status, pp.591-595.1n: Advances in Coconut Research and Development, M.K.Nair, H.H.Khan, P. Gopalasundaram and E.V.V. Bhaskara Rao, (Eds). Oxford \& IBH Publishing Company Pvt. Ltd., New Delhi, India,759 pp.

Rajamannar, M., Rao, A.P., Ramapandu, S. and Subbiah. J. 1984. Etiology and control of Tatipaka disease of Coconut-An appraisal pp.35-39. Proc. All India Sym. Coconut Diseases, Coconut Research. Station Veppankulam, Tamil Nadu. 
Rajan, P. and Mathen, K. 1984. Sophonia greeni (Distant) (Nirvanidae: Jassoidea) on leaves of coconut palm, Cocos nucifera L. J. Plantn. Crops 12 : 178-179.

Rajan, P. and Mathen, K. 1985. Proutista tnoesta (Westwood) and other additions to insect fauna on coconut palm. J. Plantn. Crops 13 : 135-136.

Rajan, P., Nair, C.P.R., Solomon, J.J., and, Geetha, L. 2002. Identification of Phytoplasma in the salivary glands of Proutista moesta (Westwood), a putative vector of coconut root (wilt) disease. J. Plantn. Crops 30 (2): 55-57.

Ramapandu, S. and Rajamannar. M. 1981. Further investigations on the etiology and control of Tatipaka disease of Coconut. Paper presented at the Third Int. Symp. Plant Path., New Delhi.

Randles, J.W. and Hatta, T. 1980. Etiological studies on virus like diseases of coconut and cardamom in India. In: Biennial Report of the Waite Agric. Res. Inst. 1978-1979. Melbourne, Australia.

Rao, A.P, 1966. Identification of Tatipaka disease of Coconut. Andhra Agric.J. 13:112-113.

Rao, P.G., Reddy, G.S., and, Subbiah, J. 1956. A new disease of coconut in Andhra State. Indian Coconut J. 9: 215-222.

Razin, S. 1983. Identification of mycoplasma colonies,pp.83-88.1n: Methods in Mycoplasmology. S.Razin, and, J.G.Tully (Eds.) Vol. 1. Academic Press, New York.

Rethinam, P., Rajamannar, M., and, Narasimhachari, C.L 1989. Tatipaka disease of coconut in Andhra Pradesh. Indian Coconut J. 20 (1): 1-4.

Sahasranaman, K.N., Pillai, N.G., Jayasankar, N.P., Potty, V.P., Varkey, T., Amma, P. G. K. and Radha, K. 1983. Mixed farming in coconut garden-Economics and its effect on root (wilt) disease, pp. 160-165. In: Coconut Research and Development. N.M. Nayer (Ed.). Wiley Eastern Ltd., New Delhi, India, 518 pp.

Sasikala, M., Mathen, K., Govindankutty, M.P., Solomon, J.J. and Geetha, L. 1988. Transmission of a mycoplasma-like organism from Cocos nucifera with root(wilt) disease to Catharanthus roseus by Cassythafilifonnis. Neth. J. Pl. Path.94: 191-194.

Seemuller, E. 1976. Investigations to demonstrate mycoplasma like organisms in diseased plants by fluorescence microscopy. Acta Hort., 67:109-112.

Shanta, P., Hariharasubramanian,V, and Pillai N.G. 1975. Possible association of tobacco mosaic virus with the root (wilt) disease of coconut. J. Plant. Crops 3: 77-80.

Shanta, P., Joseph, T., and, Lal, S.B. 1964. Transmission of root (wilt) disease in coconut. Indian Coconut. J.18: 25-28.

Solomon, J.J. 1991. Recent advances in research on root (wilt) disease of coconut. J. Plantn. Crops 19(2): 153-162.

Solomon, JT 1997. Current status of research on root (wilt) disease of coconut in India. In: Aternational Workshop on Lethal Yellowing-Like Diseases of Coconut, ST Eden-Green and F. Ofori (Eds.). Elminal Ghana, 5-10 Nov. 1995. Natural Resources Institute, Chatham, U.K. 
Solomon, J.J. and Govindankutty, M.P. 1991. Etiology. E. Mycoplasma-like organisms, pp.31-40. In: Coconut Root (Wilt) Disease, Monograph Series No. 3. M.K. Nair, K.K.N. Nambiar, P. K. Koshy and N.P. Jayasankar(Eds.). Central Plantation Crops Research Institute, Kasaragod, lndia, 92pp.

Solomon, J.J. and Geetha, L. 1993. Studies on the Ultrastructural changes in root (wilt) diseased palms. J. Plantn. Crops 21 (Suppl.): 113-118.

Solomon, J.J., Govindankutty, M. P. and Nienhaus. F . 1983. Association of mycoplasma-like organisms with the coconut root (wilt) disease in India. Z. Pflkrankh. Pflschutz. 90: 295-297.

Solomon, JT, Nair, C.P.R., Srinivasan, N., Gunasekaran, M. and Sasikala, M. 1999. Coconut root (wilt) - The malady and remedy. J. Plantn. Crops 27(2): 71-92.

Sosamma, V.K., and, Koshy, P.K. 1991. Etiology -Nematodes in coconut root (wilt) disease, pp.19-26. In: Coconut Root (Wilt) Disease, Monograph Series No. 3. M.K. Nair, K.K.N. Nambiar, P. K. Koshy and N.P. Jayasankar(Eds.). Central Plantation Crops Research Institute, Kasaragod, India, 92pp.

Sosamma C., and, Chandrasekharan, N. (1993). Changes in nutrient content of coconut water as a result of root (wilt) infection. Madras Agric. 80 (9) : 537-540.

Srinivasan, N. 1991. Occurrence of coconut leaf rot in relation to root (wilt) disease. Indian Cocon. J. 21(10): 14-18.

Srip.ivasan, N., and, Gunasekaran, M. 1994. Identification of Colletotrichum gloeosporioides, Exserohillan rostration and Gliocladium vemosini associated with leaf rot disease of Coconut in India. Cord 10 (1): 34-50.

Srinivasan, N., and, Solomon, J.J. 1992. Cultivation of spiroplasma from sesamum affected by phyllody in chick embryos. J. Curr. Biosc. 9(3) : 97-102.

Subbiah, J., and, Rao, P.G. 1963. Studies in Coconut decline in Andhra. Andhra.Agri.J.10: 58-67.

Summanwar, A.S., Raychaudhuri, S.P. and Jagadish Chandra, K. 1971. Further studies on coconut root (wilt) disease. $2^{\text {nd }}$ International Symp. on Pl. Path. January, 27" to Feb $3^{\text {rd }}$.

Summanwar,A.S., Raychaudhuri,S.P., Jagadish Chandra, K., Namaprakash and Lal, S.B. 1969. Virus associated with coconut root (wilt) disease. Curr. Sci. 38 : 208-210.

Tully, J.G. 1993. International Committee on Systematic Bacteriology-Sub Committee on the Taxonomy of Mollicutes. Minutes of the interim meetings, 1-2 Aug; 1992, Ames, lowa. Int.J.Syst.Bacteriol. 43: 394397.

Varghese, M.K., 1934. Diseases of the coconut palm. Government Press, Trivandrum 105pp.

Varkey, T. and Davis, T.A. 1960. Studies on coconut pollen with reference to the leaf and root (wilt) diseases. Indian Cocon. J. 14: 1-7. 